\title{
PENGARUH BERMAIN LEMPAR TANGKAP BOLA TERHADAP KETERAMPILAN MOTORIK KASAR ANAK USIA 5 - 6 TAHUN DI TK MELBOURN
}

\author{
Jojor Br Siregar $^{(1)}$, Damaiwaty $\mathbf{R}^{(2)}$, May Sari Lubis ${ }^{(3)}$ \\ ${ }^{(1)}$ Mahasiswa Program Studi PG PAUD FIP UNIMED \\ ${ }^{(2)}$ Dosen Program Studi PG PAUD FIP UNIMED \\ ${ }^{(3)}$ Dosen Program Studi PG PAUD FIP UNIMED \\ J1. Williem Iskandar Pasar V Medan Estate, Medan, Sumatera Utara,20371
}

Email: damaiwaty@unimed.ac.id

\begin{abstract}
Abstrak: Permasalahan pada penelitian ini adalah kurangnya keterampilan motorik kasar anak sehingga menyebabkan anak mengalami hambatan, hambatan yang terjadi disebabkan karena pembelajaran motorik kasar pada sekolah belum dilakukan secara optimal, kurang dalam melibatkan aktifitas fisik anak, anak cenderung aktif terhadap kegiatan bermain, anak hanya berlari kesana kesini dan bermain seadanya, anak kurang mampu melakukan praktik bermain melempar dan menangkap bola, meskipun ada beberapa anak yang sudah bisa melakukan lempar tangkap bola, namun masih banyak anak yang masih terlihat kaku dan masih membutuhkan bantuan guru, melakukan gerakan dengan mengikuti arahan-arahan guru. Tujuan penelitian ini adalah untuk mengetahui pengaruh permainan lempar tangkap bola terhadap keterampilan motorik kasar kelompok B di TK Melbourn. Jenis penelitian ini adalah eksperimen, desain yang digunakan dalam penelitian ini adalah Quasi Exsperimental Design dengan bentuk the equivalent time sample design. Sampel penelitian ini adalah anak kelompok B2 yang berjumlah 15 orang. Teknik pengumpulan data menggunakan uji normalitas, dan uji hipotesis (Uji-t).Hasil analisis data observasi akhir keterampilan motorik kasar pada anak dengan menggunakan uji normalitas diketahui bahwa data tidak diberi perlakuan $\mathrm{L}_{\text {hitung }}<\mathrm{L}_{\text {tabel }}$ atau $-0,9945<0,220$ dan data diberi perlakuan $\mathrm{L}_{\text {hitung }}<\mathrm{L}_{\text {tabel }}$ atau $-0,8264<0,220$ menunjukan bahwa kelompok data berdistribusi normal.Uji hipotesis dengan menggunakan uji-t pada taraf nyata $\alpha=0,05$ diperoleh $\mathrm{T}_{\text {hitung }}=3,83$ dan karena $\mathrm{dk}=14$, maka $\mathrm{T}_{\text {tabel }}=$ 1,7531. Maka $T_{\text {hitung }}=3,83>T_{\text {tabel }} 1,7531$. Berdasarkan hasil penelitian tersebut dapat disimpulkan ada pengaruh yang signifikan dari bermain lempar tangkap bola terhadap keterampilan motorik kasar anak usia 5-6 tahun di TK melbourn.
\end{abstract}

Kata Kunci: Keterampilan motorik, Permainan, Lempar tangkap bola, Anak usia 5-6 tahun. 


\section{PENDAHULUAN}

Salah satu perkembangan yang harus dicapai anak adalah perkembangan fisik motorik, yaitu dalam hal bermain lempar tangkap bola yang sangat berpengaruh terhadap keterampilan motorik kasar anak dalam hal berlari untuk melatih keterampilan morotik kasar anak pada bagian kaki yang diharapkan sudah mampu melempar dan menangkap bola dengan sesuai jarak dan tempat yang disediakan untuk taraf usia 5-6tahun.

Pada usia 5-6 tahun dalam keterampilan motorik kasar anak diharapkan sudah mampu berjalan, naik turun tangga dengan kaki secara bergantian, berlari kuat dan kencang dan sebagainya. Perkembangan fisik sangat berkaitan erat dengan perkembangan motorik anak dan sangat penting untuk dipelajari, karena perkembangan fisik akan berpengaruh terhadap perilaku sehari-hari. Kegiatan pembelajaran di Taman Kanak kanak, anak merupakan subyek yang harus mendapatkan perhatian untuk menunjang pertumbuhan dan perkembangan motoriknya.

Pengembangan keterampilan motorik kasar anak sangat penting untuk diperhatikan karena dengan memperhatikan motorik anak kita sebagai pendidik dapat mengetahui berbagai kegiatan ataupun aktivitas fisik motorik yang dilalukan anak. Aktivitas gerak yang dilakukan anak dengan bermain bagi anak usia dini merupakan suatu hal yang menyenangkan.

Bermain merupakan hal yang sangat disukai anak usia dini. Bermain dalam meningkatkan kemampuan motorik kasar anak dapat dilakukan dengan berbagai macam bentuk, misalnya : bermain peran makro, bermain kelereng, lari zigzag, dan lempar tangkap bola.

Lempar tangkap bola merupakan salah satu permainan yang menggunakan bola sebagai media, permainan lempar tangkap bola ini seringkali diterapkan bagi anak usia dini dengan tujuan dapat melatih motorik. Media dalam permainan ini adalah bola berukuran kecil ataupun besar. Selain itu permainan ini juga membutuhkan koordinasi baik antara kerja sama mata dengan tangan serta kaki anak. Gerakan melempar dan menangkap bola yang dilakukan anak dalam permainan ini juga berguna untuk melatih keseimbangan anak. Anak akan berusaha untuk tidak terjatuh saat melempar dan menangkap bola, dan anak juga akan berusaha agar lemparan yang dilakukan tepat sasaran serta berusaha agar anak mampu menangkap bola yang diarahkan kepadanya.

Pada kenyataannya dalam pengamatan yang peneliti lakukan saat observasi di TK MELBOURN keterampilan motorik kasar anak masih belum berkembang secara baik, hal tersebut terjadi disebabkan karena 
pembelajaran motorik kasar pada sekolah belum terlalu sering dilakukan yang melibatkan aktifitas fisik yang melibatkan anak-anak seperti melempar dan menangkap bola, anak cenderung aktif terhadap kegiatan bermain, anak hanya berlari kesana kesini dan bermain seadanya.

Ketika dilakukan kegiatan melempar dan menangkap bola, anak masih belum mampu melakukan praktik bermain melempar dan menangkap bola, meskipun ada beberapa anak yang sudah bisa melakukan lempar tangkap bola, namun anak masih terlihat kaku dan masih membutuhkan bantuan guru, melakukan gerakan dengan mengikuti arahan-arahan guru, dan ada juga anak hanya duduk ketika sedang bermain. Selain karna kurangnya kegiatan yang melibatkan motorik kasar anak, penyebab lainnya yaitu guru cenderung memberikan pembalajaran yang dilakukan seperti pembelajaran yang di SD dimana anak duduk diam tertib serta memperhatikan guru dan tidak boleh bermain dengan temannya. Hal tersebut dikarena tuntutan orang tua yang menginginkan anak setelah tamat TK sudah bisa membaca ,menulis dan menghitung padahal sejatinya anak usia dini diberikan waktu yang banyak untuk bermain karena dunia anak adalah dunia bermain sambil belajar.

Pernyataan ini didukung hasil penelitian yang dilakukan oleh Hesti Wijayanti (2014 : 4) Dengan judul peningkatan kemampuan motorik kasar anak melalui bermain lempar tangkap bola besar kelompok B TK Hidayah Semawung Bajaroyo Kalibawang Kulonprogo. Dimana anak pada saat melakukan suatu permainan cenderung cepat bosan. Kemudian media pembelajaran yg digunakan guru cenderung alat-alat permainan outdoor Kurangnya pemanfaatan media dalam kegiatan bermain yang melatih kemampuan motorik kasar anak dan kurangnya kegiatan bermain yang melatih motorik kasar anak

\section{KAJIAN TEORI}

Motorik kasar adalah suatu kemampuan gerak tubuh yang menggunakan otot-otot besar atau seluruh anggota tubuh, motorik kasar diperlukan agar anak dapat duduk, menendang, berlari, naik turun tangga dan sebagainya Musfiroh (2012:113). Motorik adalah proses tumbuh kembang kemampuan gerak seorang anak. pada dasarnya, perkembangan ini berkembang sejalan dengan kematangan saraf dan otot anak. sehingga, setiap gerakan sesederhana apapun, adalah hasil pola interaksi yang kompleks dari berbagai bagiandan sistem dalam tubuh yang dikontrol oleh otak. Gerak motorik kasar adalah gerak anggota badan secara kasar atau keras (Suryadi, 2010:68) 
Menurut Janice J. Beaty (2013:52) perkembangan motorik merupakan perubahan kemampuan gerak dari mulai bayi sampai dewasa dimana perkembangan motorik melibatkan berbagai aspek perilaku dan kemampuan gerak. Semakin anak bertambah besar otot-otot badan semakin menguat, serta gerak motoriknya kelihatan teratur. Ia mulai bisa berlari-lari kecil, melompat, meloncat, dan skipping.

Proses perkembangan anak dapat diamati dari perkembangan motoriknya. Perkembangan motorik sangat berkaitan dengan gerakan tubuh ketika anak melakukan aktivitas. Menurut Hurlock (2013:150) bahwa: Perkembangan motorik berarti perkembangan pengendalian gerakan jasmaniah melalui kegiatan pusat syaraf, otot syaraf dan otot yang dikoordinasikan. Pengendalian tersebut berasal dari kegiatan masa yang ada pada waktu lahir. Sebelum perkembangan tersebut terjadi, anak akan tetap tidak berdaya.

Perkembangan motorik sangat dipengaruhi oleh organ dan fungsi syaraf atau otak. Seiring dengan berkembangnya periode usia, maka keterampilan anak akan bertambah. Semakin anak berusia semakin terampil pula dalam perubahan perilaku motoriknya. Pendapat lain diungkapkan oleh Saputra (2005:114) bahwa; perkembangan motorik adalah suatu perubahan dalam perilaku motorik yang memperlihatkaninteraksi kematangan makhluk dan lingkungannya.

Pada penelitian ini perkembangan yang akan diamati adalah perkembangan motorik kasar anak. Menurut Sujiono (2007:1.13), Gerakan motorik kasar dalam perkembangannya lebih dulu berkembang daripada motorik halus yang dapat terlihat saat anak sudah menggunakan otot-otot kakinya untuk berjalan sebelum anak dapat mengontrol tangan dan jari-jarinya untuk menggunting dan meronce. Oleh karena itu, mengingat pentingnya motorik kasar bagi anak usia dini, maka pada penelitian ini ditekankan pada kemampuan motorik kasar.

Menurut Sujiono, Bambang (2011:73) ada beberapa unsur keterampilan motorik kasar yaitu:

1. Kekuatan adalah keterampilan sekelompok otot untuk menimbulkan tenaga sewaktu kontraksi

2. Koordinasi adalah keterampilan untuk mempersatukan atau memisahkan dalam satu tugas yang kompleks

3. Kecepatan adalah sebagai keterampilan yang berdasarkan kelenturan dalam satuan waktu tertentu

4. Keseimbangan adalah keterampilan seseorang untuk mempertahankan tubuh dalam berbagai posisi 
5. Kelincahan adalah keterampilan seseorang mengubah arah dan posisi tubuh dengan cepat dan tepat pada waktu bergerak dari titik ketitik lain.

Bermain merupakan kebutuhan bagi anak. Bermain bagi anak usia dini merupakan proses belajar yang menyenangkan. Menurut Furqon (2008:4) menyatakan bahwa bermain adalah aktifitas yang menyenangkan, serius dansukarela, di mana anak berada dalam dunia yang tidak nyata atau sesungguhnya. Kegiatan bermain memberikan kebebasan kepada anak untuk berimajinasi, berekplorasi, dan menciptakan suatu bentuk kreativitas dengan hal-hal yang menyenangkan.

Hal ini sejalan dengan pendapat Musfiroh (2005:2) bahwa bermain adalah suatu kegiatan yang dilakukan demi kesenangan secara sukarela, tanpa paksaan atau tekanan dari pihak luar. Melalui bermain anak memiliki banyak kesempatan bereksplorasi sehingga pemahaman tentang konsep maupun pengertian dasar suatu pengetahuan dapat dipahami oleh anak dengan lebih mudah.

Berdasarkan pendapat beberapa ahli di atas dapat disimpulkan bahwa bermain adalah aktivitas yang menyenangkan bagi anak usia dini yang dilakukan dengan sukarela atau tanpa paksaan secara berulang-ulang danmenimbulkan kepuasan. Bermain merupakan suatu kebutuhan bagi anak yangdapat memberikan dampak yang positif untuk seluruh aspek perkembangananak. Melalui bermain dapat memberikan kesempatan yang lebih banyakkepada anak untuk bereksplorasi sehingga pemahaman tentang konsepmaupun pengertian dasar suatu pengetahuan dapat dipahami oleh anak dengan lebih mudah.

\section{METODE PENELITIAN}

Pada penelitian ini penulis menggunakan jenis penelitian Kuantitatif. Jenis penelitian yang digunakan dalam penelitian ini adalah jenis metode penelitian eksperimen. Menurut Sugiyono (2013:107) metode penelitian eksperimen adalah metode penelitian yang digunakan untuk mencari pengaruh perlakuan tertentu terhadap yang lain dalam kondisi yang terkendalikan.

Desain yang digunakan dalam penelitian ini adalah Quasi Exsperimental Design dengan bentuk the equivalent time sample design.populasi dalam penelitian ini adalah seluruh anak kelompok B yang berusia 5-6 tahun di TK MELBOURN Binjai yang terdiri dari 3 kelas yaitu B1 yang terdiri dari 23 anak, B2 yang terdiridari 24 anak, B3 yang terdiri dari 23 anak, Jumlah anak dari kelas B1 sampai dengan B3 berjumlah 70 anak. Pengambilan sampel diambil dengan menggunakan cara memasukan 
kertas yang berisi (B1,B2,B3) kedalam wadah lalu dikoco, setelah dikocok maka kelas yang terpilih adalah kelas B2 yang berjumlah 15 anak

Teknik pengumpulan data adalah cara yang digunakan oleh peneliti untuk mengumpulkan dan memperoleh data penelitian. Teknik pengumpulan data yang digunakan dalam penelitian ini adalah observasi terstuktur. Teknik analisis data adalah cara untuk memudahkan atau menyederhanakan data dalam bentuk yang lebih mudah dibaca dan dimengerti untuk menguasai dan menganalisis data agar dapat dipertanggung jawabkan secara alamiah, maka data tersebut perlu diuji bdan di analisis secara sistematis. Dalam hal ini analisis data dimaksudkan untuk mengolah data-data yang diperoleh dari penilitian ini adalah statistik deskriptif

\section{HASIL PENELITIAN DAN PEMBAHASAN}

Hasil tabulasi data observasi Keterampilan Motorik Kasar diberi perlakuan bermain Lempar tangkap bola. digambarkan pada Tabel sebagai berikut:

Tabel Distribusi Frekuensi Nilai Keterampilan Motorik Kasar Anak Diberi Perlakuan Bermain Lempar Tangkap Bola

\begin{tabular}{|l|l|l|l|}
\hline Nilai Interval & Frekuensi & Presentase & $\begin{array}{l}\text { Capaian } \\
\text { Perkembangan }\end{array}$ \\
\hline $0-10$ & 0 & $0 \%$ & MB \\
\hline $11-20$ & 11 & $73,33 \%$ & BSH \\
\hline $21-30$ & 4 & $26,67 \%$ & BSB \\
\hline Jumlah & $\mathbf{1 5}$ & $\mathbf{1 0 0} \%$ & \\
\hline & $\bar{X}=\mathbf{1 7 , 9}$ & SD $=\mathbf{6 , 3 5}$ & \\
\hline
\end{tabular}

Tabel di atas menggambarkan bahwa nilai keterampilan motorik kasar anak yang memiliki nilai $0-10$ berjumlah $0 \%$ dikategorikan mulai berkembang (MB), nilai 11-20 berjumlah 11 orang $(73,33 \%)$ dikategorikan berkembang sesuai harapan (BSH), dan nilai 21-30 berjumlah $4(26,67 \%)$ dikategorikan berkembang sangat baik (BSB), dengan nilai rata-rata $(\bar{X}=17,9)$ 


\section{Grafik dan Presentase Nilai Keterampilan Motorik Kasar Anak yang Diberi Perlakuan Bermain Lempar Tangkap Bola}

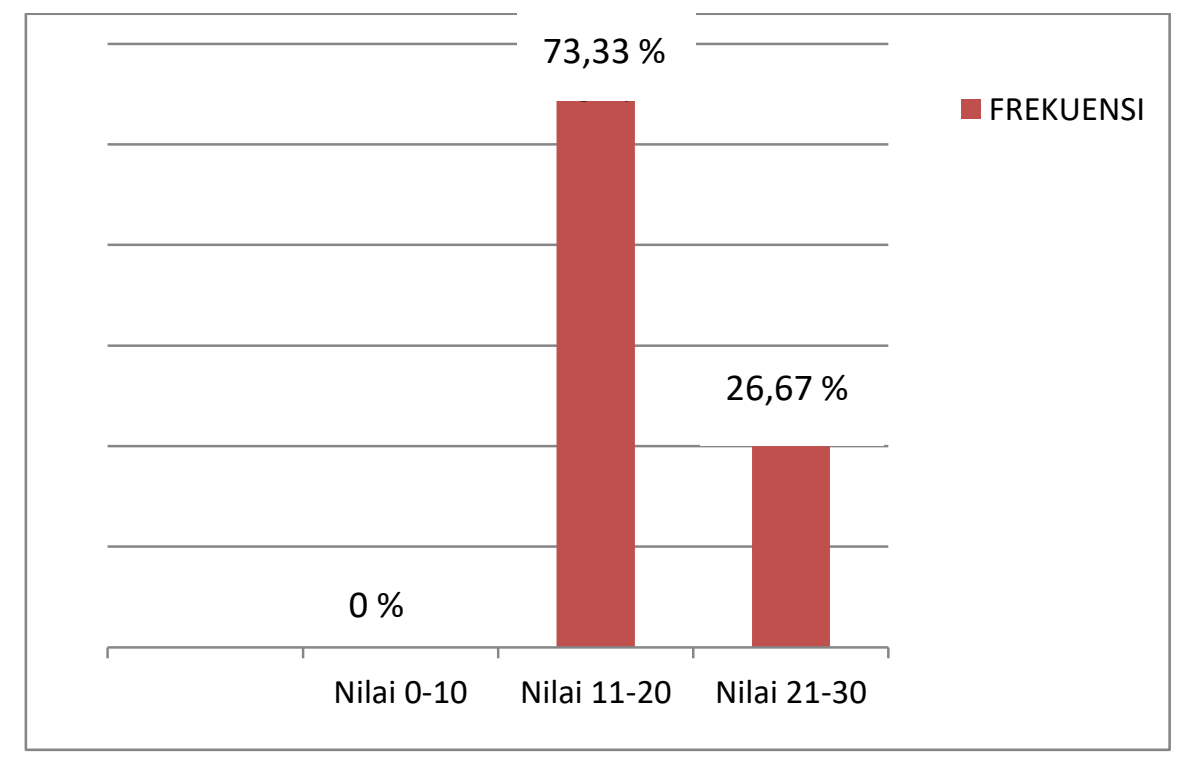

Dari grafik di atas terlihat, 0\% anak dengan nilai 0-10 dengan kategori mulai berkembang (MB), 11 orang anak $(73,33 \%)$ berada pada nilai 11 20 dengan kategori berkembang sesuai harapan (BSH), dan 4 orang anak (26,67\%) berada pada nilai 21-30 dengan kategori berkembang sangat baik(BSB).

Hasil penelitian pengaruh bermain lempar tangkap bola terhadap keterampilan motorik kasar anak usia 5-6 tahun, dilakukan dengan membandingkan data tidak diberi perlakuan dan data yang diberi perlakuan.

Hasil observasi diketahui bahwa data tidak diberi perlakuan, dengan sampel yang berjumlah 15 orang, digambarkan dalam distribusi frekuensi nilai keterampilan motorik kasar anak yaitu anak yang memiliki nilai 010 berjumlah 7 (46,66\%) dikategorikan Mulai berkembang (MB), nilai 11-20 berjumlah 8 orang $(53,34 \%)$ dikategorikan berkembang sesuai harapan $(\mathrm{BSH})$, dan nilai 21-30 berjumlah 0 (0\%) dikategorikan berkembang sangat baik (BSB),skor terendah 10 dan skor tertinggi 13, range 3, kemudian dilakukan perhitungan tidak diberi perlakuan menghasilkan nilai rata-rata skor sebesar 10,8, standar deviasi skor 0,9 dan varians skor 0,88 . 
Hasil untuk data diberikan perlakuan digambarkan dalam distribusi frekuensi nilai kemampuan anak mengenal konsep bilangan yaitu anak yang memiliki nilai 0-10 berjumlah $0 \%$ dikategorikan mulai berkembang (MB), nilai 11-20 berjumlah 11 orang (73,33\%) dikategorikan berkembang sesuai harapan (BSH), dan nilai 21-30 berjumlah 4 (26,67\%) dikategorikan berkembang sangat baik (BSB), skor terendah 15 dan skor tertinggi 21, range 6 . Hasil perhitungan diperoleh rata-rata skor sebesar 17,9, standar deviasi skor 6,35, dan varians skor 2,51.

Dilihat dari deskripsi data jika dibandingkan dua kelompok tersebut terdapat perbedaan antara tidak diberi perlakuan dan diberi perlakuan. Hasil diberi perlakuan lebih baik dari hasil tidak diberi perlakuan, hal ini disebabkan karena adanya bermain lempar tangkap bola sehingga anak dapat mengembangkan keterampilan motorik kasar anak seperti, kekuatan,koordinasi,kecepatan,keseimbangan dan kelincahan.

Melalui bermain lempar tangkap bola,keterampilan motorik kasar anak terlihat lebih baik, hasil penelitian menunjukkan bahwa dengan diberikan perlakuan bermain lempar tangkap bola ternyata hasilnya meningkat dibandingkan dengan tidak diberi perlakuan. Berdasarkan penelitian yang dilakuakan di TK Melbourn dapat dinyatakan bahwa dengan adanya bermain Lempar tangkap bola dalam pembelajaran berpengaruh terhadap keterampilan motorik kasar anak usia 5-6 tahun.

\section{SIMPULAN}

Berdasarkan hasil penelitian yang dilakukan maka dapat diambil kesimpulan bahwa:

1. Dari hasil penelitian,adanya pengaruh yang signifikan bermain lempar tangkap bola terhadap keterampilan motorik kasar anak.

2. Sesuai dengan hasil uji hipotesis yang memiliki $\mathrm{T}_{\text {hitung }}=3,83>\mathrm{T}_{\text {tabel }}$ 1,7531 dengan taraf $\alpha 0,05$, sehingga data menunjukan adanya perbedaan yang signifikan. Nilai rata-rata tidak diberi perlakuan 10,8 dan diberi perlakuan 17,9 ,bermain lempar tangkap bolamemberikan pengaruh yang positif terhadap keterampilan motorik kasaranak.

\section{DAFTARPUSTAKA}

Arikunto, S. 2013. Prosedur Penelitian Suatu Pendekatan Praktek. PT Rineka Cipta: Jakarta

Furqon, M.H. 2008. Mendidik Anak dengan Bermain (Buku Pegangan Guru Penjas di Sekolah Dasar). Universitas Sebelas Maret: Surakarta. 
Harlock, B, Elizabeth. 2013. Child Development. (Terjemahan: Med Meitasari Tjandrasa dan Muchicah Zarkasih). Erlangga: Jakarta.

Musfiroh, Tadkirotun. 2005. Bermain Sambil Belajar dan Mengasah Kecerdasan. Jakarta: Depdiknas.

Nurani, Yuliani \& Sujiono. 2010. Bermain Kreatif Berbasis Kecerdasan Jamak. PT. Indeks: Jakarta.

Saputra, M., Yudha dan Rudyanto. 2005. Pembelajaran Kooperatif untuk Meningkatkan Keterampilan Motorik Anak TK. Depdiknas: Jakarta.

Sugiyono. 2011. Metode Penelitian Kuantitatif dan R\&D. Alfabeta: Jakarta. 2013. Metode Penelitian Pendidikan. Alfabeta: Jakarta.

Sujiono, Bambang., dkk. 2007. Metode Pengembangan Fisik. Universitas Terbuka: Jakarta. 